\title{
The Impact of Female Labour Force Participation on Household Income Inequality in Switzerland ${ }^{1}$
}

\author{
Ursina Kuhn* and Laura Ravazzini ${ }^{* / * *}$
}

\begin{abstract}
This contribution investigates the link between female labour force participation and household income inequality using data from the Swiss Household Panel (2000-2014). Through index decomposition analyses, we find that female labour force participation has slightly attenuated household income inequality over time. Women's entry into the labour market, higher work percentages within part-time work - but not the shift from part-time to full-time work - and the weak correlation in partner's earnings have contributed to this effect. Keywords: female labour force participation, income inequality, part-time work, index decomposition, household types
\end{abstract}

\section{Erwerbstätigkeit der Frauen und Ungleichheit der Haushaltseinkommen in der Schweiz}

Zusammenfassung: Dieser Beitrag untersucht den Zusammenhang zwischen der Erwerbsbeteiligung der Frauen und der Ungleichheit der Haushaltseinkommen anhand der Daten des Schweizer Haushalt-Panels (2000-2014). Eine Zerlegung von Ungleichheitsindizes zeigt einen ausgleichenden Einfluss der steigenden Frauenerwerbstätigkeit auf die Einkommensverteilung. Der Eintritt in den Arbeitsmarkt, höhere Teilzeit-Arbeitspensen, aber nicht der Wechsel von Teilzeit zu Vollzeit, sowie die schwache Korrelation zwischen den Löhnen der Partner sind für diesen Effekt verantwortlich.

Schlüsselwörter: Erwerbsbeteiligung von Frauen, Einkommensungleichheit, Teilzeitbeschäftigung, Indexzerlegung, Haushaltstypen

\section{Participation des femmes au marché du travail et inégalité de revenu des ménages en Suisse}

Résumé: Cet article traite du lien entre le taux d'activité des femmes et l'inégalité de revenu des ménages à partir des données du Panel suisse de ménages (2000-2014). Une analyse de décomposition de mesures d'inégalité montre que l'augmentation du taux d'activité des femmes a tendance à réduire cette inégalité. Les causes principales en sont l'entrée des femmes sur le marché de travail, l'augmentation des taux d'occupation du travail à temps partiel - mais non pas le passage du travail à temps partiel au travail à plein temps - et la faible corrélation des revenus entre partenaires.

Mots-clés: participation des femmes au marché du travail, inégalité de revenu, emploi à temps partiel, décomposition d'indices, types de ménage

\footnotetext{
* Swiss Centre of Expertise in the Social Sciences (FORS), University of Lausanne, CH-1015 Lausanne, ursina.kuhn@fors.unil.ch.

** University of Neuchâtel, CH-2000 Neuchâtel, laura.ravazzini@unine.ch.

1 This contribution is based on the project "Income and wealth inequality, deprivation and wellbeing in Switzerland, 1990-2013," financed by the Swiss National Science Foundation (project 100017_143320). This study was realised using the data collected by the Swiss Household Panel (SHP), which is based at FORS; the SHP is financed by the Swiss National Science Foundation. We would like to address special thanks to the anonymous reviewers for their careful reading of our manuscript and for their highly appreciated comments and suggestions, which have significantly improved the quality of this publication.
} 
The growth of female employment is one of the major socio-economic changes in most societies. A changed division of labour within couples, evolving social norms, technological changes and the expansion of education are drivers of this transition from unpaid housework to paid work. The increasing income earned by women has consequences for household income. Household income includes all income sources by all household members and takes into account the sharing of resources among household members. Because it illustrates the economic well-being of individuals, household income inequality is a key inequality measure. Female employment boosts the level of household income, but the effect on its distribution is not a priori clear.

Whether more female employment is good or bad for household income inequality depends on which women work more. If it is mostly women in lowincome households who work, inequality should decrease, whereas if it is mostly women in high-income households who increase their working hours, inequality should increase. Although most recent contributions find egalitarian effects at the household level, previous empirical analyses have shown mixed results.

In Switzerland, the link between female labour force participation and household income inequality has not been investigated so far. Considering that comparative analyses stress the importance of the activity rate for household income inequality (Pasqua 2008; Kollmeyer 2012), Switzerland presents an interesting case study. The participation rate is high and part-time work is more common among women than in any other OECD country (OECD StatExtract 2015). ${ }^{2}$ In parallel to the rise of the activity rate from $68 \%$ in 1991 to $79 \%$ in 2014 , the typical household structure has gradually changed from a 1-0 type (men working full-time, women not working) to a 1-0.5 type (men working full-time, women working part-time) (Bühler et al. 2002). Another important characteristic of Switzerland is that, unlike in many other countries, its household income inequality has remained at the same level since 2000 (SFSO 2014; Suter et al. 2016) and is now below the European average (Eurostat 2015). Therefore, our research question is whether high and rising female employment has contributed to keeping household income inequality in Switzerland relatively low.

Apart from adding evidence for Switzerland, this article contributes to a better understanding of the impact of part-time work on household income inequality. Although some studies consider part-time work to be a driver of household income inequality (Esping-Andersen 2009; OECD 2013), this aspect has never been empirically addressed in detail. Typically, studies look at how earners and non-earners are grouped in households, but they do not distinguish between different work percentages.

2 In 2014, 59.2\% of active women in Switzerland worked part-time, followed closely by the Netherlands, with $57.9 \%$. Part-time percentages are computed according to national definitions. The intensity of part-time work is similar for women of different age groups. 
In this contribution, we first discuss the different potential channels through which female employment affects household income inequality. After a brief literature review, we discuss methods and data from the Swiss Household Panel (2000 to 2014). To measure inequality in income distribution, we use the Theil index and the Coefficient of Variation. Inequality decompositions and counterfactual simulations serve as the main methodological tools. Our main results suggest that women's stronger labour force participation has contributed to keeping household income inequality relatively low in Switzerland.

\section{Theory}

Household income inequality is determined by many different factors (see e. g. Jenkins 1995; OECD 2015), of which we discuss only those related to labour force participation. The main dependent variable of our analysis, household income inequality, includes labour income from employment and self-employment, asset income, private and public transfers and imputed rent. Since we are not interested in the effects of the tax system, we do not include direct taxes.

Figure 1 illustrates the different channels through which increasing female employment may influence household income inequality. We distinguish between effects from changes in the household composition (e.g. more single households) and effects from changing working patterns within households (e.g. household labour supply). Earnings inequality at the individual level is determined by labour force participation, by the variation in working hours and hourly wages and by the relation between working hours and hourly wages. The correlation of earnings between members of the same household and the correlation between income sources play an additional role.

Looking at the different channels of Figure 1, we can formulate some expectations on how the rise in female labour force participation in Switzerland affects household income inequality. Table 1 summarises these hypotheses. First, if more women work, there are fewer women with no working hours (and thus zero earnings), which means that inequality in working hours among all working-age women shrinks (H1a). Second, the effect on the variation of hours depends on whether women with a relatively low work percentage or with a relatively high work percentage increase their hours. Because working hours are limited at the top (we do not take into account overtime here), we expect that rising work percentages bring a lower heterogeneity in hours ( $\mathrm{H} 1 \mathrm{~b})$. The lower variation in working hours ( $\mathrm{H} 1 \mathrm{a}$ and $\mathrm{H} 1 \mathrm{~b}$ ) would clearly have an equalising effect on earnings and household income.

The equalising effect from the variation in working hours might be amplified or mitigated by a positive or negative correlation between hours and hourly wages. There are two reasons to expect a positive correlation in Switzerland (H2), which 
Figure 1 Determinants of household income inequality

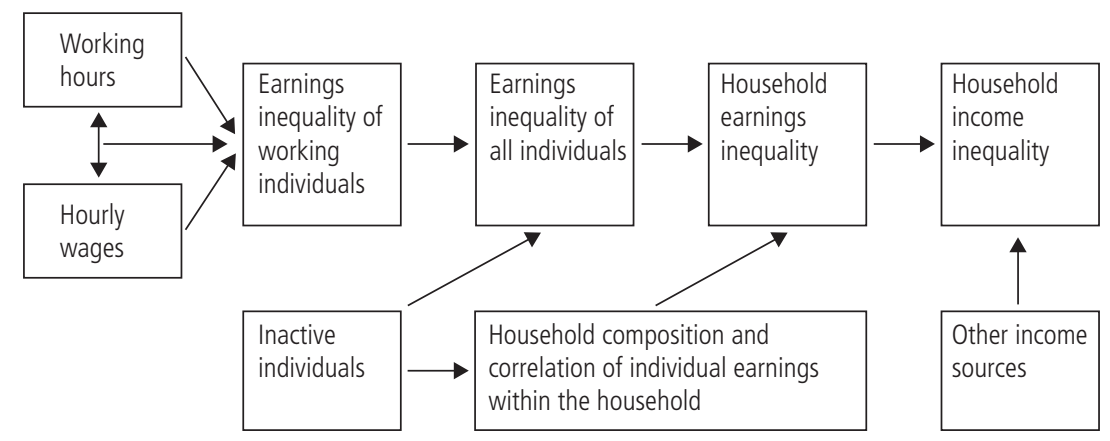

partially offsets the equalising effect of H1b. First, part-time work might be worse paid than full-time work. Such a part-time penalty is the reason that the OECD (2013) sees part-time work as a potential driver of income inequality. Second, positive wage elasticities in labour supply models suggest that the wage potential positively affects working hours (Gerfin and Leu 2007).

After having discussed the effects on individual earnings inequality, we now turn to the household level. The role of the correlation between the different income sources is a rather complex issue. With the working patterns of women and men becoming more similar, we expect that the earnings of women and men should increasingly resemble each other over time. Consequently, the correlation between men's and women's earnings should become more positive (H3a). However, the correlation between income sources does not only reflect the similarity in working hours, but also the household structure (e.g. the share of single households), the similarity in wage levels between partners (e.g. due to assortative mating) and the relationship between the labour supply and partners' earnings. If it is mostly women with high-earning partners who increase their working hours, household income inequality will increase, whereas if it is mostly women with low-earning partners who increase their working hours, inequality will decrease. In Switzerland, the female labour supply depends negatively on the wage level of their partners (Gerfin and Leu 2007). Other studies show that, due to the tax system and income-dependent child-care costs, high work percentages are particularly unattractive for women with children and a high-earning partner (Bütler and Ruesch 2009; Schwegler et al. 2012). We therefore expect that women with high-earning husbands have increased their working hours to a smaller extent than women with low-earning husbands. Consequently, the correlation between couples' earnings should have become less positive over time (H3b). The two hypotheses $3 \mathrm{a}$ and $3 \mathrm{~b}$ point in different direc- 
Table $1 \quad$ Hypotheses on the impact of increasing female labour force participation on household income inequality

\begin{tabular}{|c|c|c|c|}
\hline & Type of change & Reason & $\begin{array}{l}\text { Effect on household } \\
\text { income inequality }\end{array}$ \\
\hline $\mathrm{H} 1 \mathrm{a}$ & $\begin{array}{l}\text { All women: Variation in working } \\
\text { hours decreases over time }\end{array}$ & $\begin{array}{l}\text { More women work: Fewer inactive } \\
\text { women with zero earnings }\end{array}$ & Equalising \\
\hline $\mathrm{H} 1 \mathrm{~b}$ & $\begin{array}{l}\text { Working women: Variation in } \\
\text { working hours decreases over } \\
\text { time }\end{array}$ & $\begin{array}{l}\text { Women increase their working hours, } \\
\text { fewer women with low work percent- } \\
\text { ages }\end{array}$ & Equalising \\
\hline $\mathrm{H} 2$ & $\begin{array}{l}\text { Working women: Positive } \\
\text { correlation hours-wage level }\end{array}$ & $\begin{array}{l}\text { Positive own-wage elasticity, part-time } \\
\text { penalty }\end{array}$ & Disequalising \\
\hline $\mathrm{H} 3 \mathrm{a}$ & $\begin{array}{l}\text { Household: Correlation of } \\
\text { partners' earnings more positive } \\
\text { over time }\end{array}$ & $\begin{array}{l}\text { Partners have more similar working } \\
\text { hours }\end{array}$ & Disequalising \\
\hline $\mathrm{H} 3 \mathrm{~b}$ & $\begin{array}{l}\text { Household: Correlation of } \\
\text { partners' earnings less positive } \\
\text { over time }\end{array}$ & $\begin{array}{l}\text { Women with high-earning partners } \\
\text { increase their working hours less }\end{array}$ & Equalising \\
\hline $\mathrm{H} 4$ & $\begin{array}{l}\text { Household: inequality in income } \\
\text { sources: Women's earnings } \\
\text { become more relevant for } \\
\text { household income }\end{array}$ & $\begin{array}{l}\text { Earnings are more equally distributed } \\
\text { than income from other sources (as- } \\
\text { sets, transfers, pensions) }\end{array}$ & Equalising \\
\hline $\mathrm{H} 5 \mathrm{a}$ & $\begin{array}{l}\text { Household structure: More single } \\
\text { households }\end{array}$ & $\begin{array}{l}\text { Women in single households work } \\
\text { more than women in couple house- } \\
\text { holds, no pooling of household income }\end{array}$ & Disequalising \\
\hline $\mathrm{H} 5 \mathrm{~b}$ & $\begin{array}{l}\text { Household structure: More single- } \\
\text { mother households }\end{array}$ & $\begin{array}{l}\text { Single mothers work more than moth- } \\
\text { ers living with their partner, no pooling } \\
\text { of household income, generally low } \\
\text { income levels }\end{array}$ & Disequalising \\
\hline
\end{tabular}

tions and might offset each other. Overall, findings from various countries suggest that the correlation between female earnings and other income components has increased over time and has therefore had a disequalising effect on household income inequality (Karoly and Burtless 1995; Schwartz 2010).

A straightforward impact of higher female labour supply is that women's earnings contribute more strongly to total household income. If women's earnings are more equally distributed than other income sources, more female earnings reduce household income inequality. Considering that capital income (Piketty 2014) is highly unequal and that pensions and social transfers are unequally distributed among the working-age population (because only a small share of households receives these incomes) we expect this to be the case. Therefore, we expect a further equalising impact of female labour force participation on household income inequality (H4). 
Our last hypothesis concerns the household composition. Because women living in single households tend to work more than women living in couple households, we can see the rising number of single households as a cause of rising female labour force participation. Because single households tend to be more unequal than larger households (there is no pooling or redistribution of income among household members), a greater number of single households amplifies household income inequality ( $\mathrm{H} 5 \mathrm{a})$. This seems likely to be true in the Swiss context. Although it is not focused on female labour force participation, the research conducted by Ernst et al. (2000) on Switzerland shows that inequality among dual-earner households was clearly lower than among single-earner households. The same reasoning applies to single mothers, who also tend to work more than mothers living with a partner. Moreover, single mothers tend to have particularly low household income and a high variation in earnings, which reinforces this disequalising effect $(\mathrm{H} 5 \mathrm{~b})$. This is confirmed by studies in many developed countries, where single parenthood contributes to income inequality (Western et al. 2008; Kollmeyer 2012).

Notwithstanding the multitude of our hypotheses, there might be other potential impacts of female labour force participation on household income inequality, for example on inequality in hourly wages. Our discussion has not taken into account other changes occurring over time, such as changes in the tax system, business cycles or changes in the industrial structure or the unemployment rate. We also neglect the possible effects of more male part-time work as a result of a changed division of labour within couples. ${ }^{3}$

\section{Literature review}

Although the issue of female earnings has received considerable attention in the literature on income inequality, contributions have so far focused on few countries. While there is extensive evidence for the USA (Cancian and Reed 1999; Daly and Valletta 2006; Pencavel 2006; Larrimore 2014), there is scarce empirical research for European countries (exceptions are Breen and Salazar (2010) on the UK and Del Boca and Pasqua (2003) on Italy). This is surprising, considering that comparative studies show large differences between countries (Cancian and Schoeni 1998; EspingAndersen 2007; Pasqua 2008; Harkness 2013). Previous findings in the literature show that women's entry into the labour market contributes to lower household income inequality. The few studies that report the opposite effect were mostly published more than 20 years ago (Ryscavage et al. 1992; Karoly and Burtless 1995).

An important drawback of comparative studies is that they do not involve an analysis over time. Rather, they test whether observed income inequality is higher or lower compared to a situation where no women work. Such approaches cannot

3 We have tested these effects, but we found that the increase in male part-time work is marginal and not relevant for household income inequality. 
show the effect of other changes in female employment, most importantly when part-time working women increase their working hours. The same limitation applies to aggregate-level analyses that link female employment rates to income inequality (e.g. Kollmeyer 2012). To find the effect of an increase in female labour force participation over time, data on different time points is required.

The study by Breen and Salazar (2010) on the UK was one of the first to also include single households. This is important not only for the purpose of drawing inferences about the (working-age) population, but also to take the relationship between having a partner and the labour supply into account. Their study looks not only at female labour force participation, but also at assortative mating and, most importantly, educational expansion. Their results show that these aspects have hardly contributed to the increasing income inequality between households that, in the case of the UK, was driven by the rise in unemployment among the male population.

More recently, Larrimore (2014) has disentangled the different drivers of income inequality in the United States using shift-share decomposition of inequality indices for the 1980s, 1990s and 2000s by employment status, marriage rate and the correlation of spouses' earnings. This last aspect was a main driver of the steep rise in inequality in the 1990 s, whereas a rise in female earnings inequality and the unemployment rate made inequality slowly increase in the 2000s. Female employment moderated income inequality growth in the 2000 s, but was unable to reduce the growth in inequality in more recent years.

Following Breen and Salazar (2010) and Larrimore (2014), this paper includes different household types according to the cohabitation and employment status of all their members and, in addition, distinguishes between different work percentages. While we acknowledge the interrelatedness of education, assortative mating and employment, as illustrated by Blossfeld and Buchholz (2009), we do not go into the different causes of female labour force participation, but concentrate on the consequences in terms of household income inequality.

\section{Data and methods}

\subsection{Data and operationalisation}

We use data from the Swiss Household Panel (SHP) covering the years 2000 to 2014. Because the SHP includes the income and work percentages of all individuals in the household, it is well suited for our purpose. Although we analysed the data for all years, we present here results for only 2000, 2004, 2009 and 2014, as female labour participation did not change abruptly from one year to another. ${ }^{4}$

$4 \quad$ We selected the years in order to include the first and last available year in the SHP $(2000,2014)$ and similar time intervals in-between. In the few cases where our results varied between the years, we state this explicitly in the text. 
We focus on individuals of working age and do not limit the analysis to households composed of couples. We include all households where the head is between 25 and 64 years old ( $\mathrm{n}$ in $2000=3589$, in $2004=4307$, in 2009=3261, in $2014=5186$ ). The reason for this age range is that by the age of 25 , most individuals have finished their education and by the age of 65 , most are retired. The main income earner within the household has been designated as the household head. The units of analysis are individuals and weights are used to correct for sample selection and non-response. Household income has been deflated using the 2005 consumer price index and adjusted for household size using the modified OECD scale, which assigns a weight of 1 to the first adult, 0.5 to each additional adult (14 years and older) and 0.3 to each child. We top-coded extremely high values (income above the 99.75 percentile), as these outliers strongly influence inequality measures, in particular the coefficient of variation, which is sensitive to high income (Salverda et al. 2009).

For yearly income in the SHP, we use variables provided from the SHP-CNEF file. ${ }^{5}$ Hourly wages have been computed at the basis of monthly wages and weekly working hours and are top-coded at 10 times the median wage. The measurement of part-time work is crucial for our analysis. In line with definitions by the International Labour Organization (ILO) and the Swiss Federal Statistical Office, we consider individuals working at least six hours per week as active, and individuals working at least 36 hours a week as full-time workers. For some analyses, we further distinguish between small part-time work (6-19 hours) and higher part-time work (20-35 hours). ${ }^{6}$ We are aware that the categorisation of working hours into three (or four) groups has consequences on the results (although not on the main findings). However, considering that previous studies only identified two categories (working vs not working) and did not consider heterogeneity in working hours among active individuals, we think that our approach is already revealing.

\subsection{Decomposition methods}

The empirical aim of this article is to test how the recent rise in female employment has affected household income inequality. We use different decomposition methods and counterfactual distributions. Some of the hypotheses presented in Section 2 will be addressed by descriptive statistics.

5 Details of income imputation are available from the SHP documentation.

6 To distinguish work intensities, we have considered weekly working hours (usual hours and contractual hours), work percentages and occupational status from the grid questionnaire. Individuals with yearly earnings below CHF 12000 are considered inactive, while full-time working individuals have yearly earnings of at least CHF 36000 . Further details can be obtained from the authors upon request. 


\subsubsection{Factor decomposition}

Factor decompositions separate household income into different additive income components. In our analysis, we consider three factors: female labour income (f), male labour income $(\mathrm{m})$ and other income sources (ot).

$$
Y=Y_{f}+Y_{m}+Y_{o t}
$$

In line with previous studies, we chose the coefficient of variation (CV) as the inequality index due to its easy decomposability. The values of the $\mathrm{CV}$ are positive but not limited at the top and are comparable across groups and time points. The CV can be decomposed into three elements (Shorrocks 1982): the inequality in each factor $\left(C V_{k}\right.$ for factor $\left.\mathrm{k}\right)$, the correlation between a pair of income components $(p)$, and the share of each component in the total income of the household (for factor $\mathrm{k})$. Decomposing the CV for our three income components gives:

$$
\begin{aligned}
C V_{y}^{2}= & S_{m}^{2} C V_{m}^{2}+S_{f}^{2} C V_{f}^{2}+S_{o t}^{2} C V_{o t}^{2}+2 \rho_{m, f} S_{m} S_{f} C V_{m} C V_{f}+2 \rho_{m, o t} S_{m} S_{o t} C V_{m} C V_{o t} \\
& +2 \rho_{f, o t} S_{f} S_{o t} C V_{f} C V_{o t}
\end{aligned}
$$

Increased female labour force participation influences income inequality in three different ways: inequality in female earnings $\left(\mathrm{CV}_{\mathrm{f}}\right)$, women's share of total household income $\left(S_{f}\right)$ and the correlation of women's earnings with men's earnings $\left(p_{m, f}\right)$ and with other income components $\left(p_{o t, f}\right)$. A common misconception regarding the impact of female labour force participation on household income is to draw conclusions about the general effect from just one of these components. Several contributions that have found a disequalising effect of women's labour force participation indeed suffer from these methodological problems. For example, higher inequality in women's earnings compared to men's earnings or the increased correlation between spouses' earnings over time are not sufficient to explain the disequalising effect of female employment.

Shift-share analysis can isolate the effect of female labour force participation on inequality by varying one or several of the components of the decomposition. To assess the impact over time using two time points $(t, t+1)$, we compute inequality under the assumption that only some elements of the CV have changed to $t+1$ values, but the other elements have remained at their previous levels $(\mathrm{t})$.

\subsubsection{Decomposition by population groups}

An alternative approach is to compare inequality in different household types, typically distinguishing between dual-earner couples, male- and female-breadwinner couples, and non-working couples (Pasqua 2008; Harkness 2013). This approach is complementary to factor decompositions, which cannot separate the effects due to changes in the household composition (e.g. more single women or more single mothers) from effects due to changes within groups. For example, single-men households and households with a non-working wife are treated in the same way in 
factor decompositions because both are households with zero female labour income. ${ }^{7}$ Similarly, factor decompositions cannot explicitly distinguish between full-time and part-time work. The main disadvantage of decompositions by groups is that discrete groups are necessary.

The decomposition of inequality by groups can tell us to what extent inequality varies due to changes in the proportion of individuals in each group, changes in within-group inequality and changes in inequality between the different groups. Moreover, we are able to compare part-time and full-time work using a counterfactual analysis. We use the Theil index, which can be expressed as the weighted sum of inequality between groups plus inequality within each level:

$$
T=\frac{1}{n} \sum_{i}^{N} \frac{x_{i}}{\bar{x}} \ln \left(\frac{x_{i}}{\bar{x}}\right)=\sum_{j}^{J} p_{j} \frac{\bar{x}_{J}}{\bar{x}} \ln \left(\frac{\bar{x}_{J}}{\bar{x}}\right)+\sum_{j}^{J} p_{j} \frac{\bar{x}_{j}}{\bar{x}} T_{j}
$$

where $\mathrm{n}$ is the total number of individuals $i, x_{i}$ the individual earnings and $\bar{x}$ mean earnings, $\mathrm{j}$ represents a group, $p_{j}$ is the proportion of people in group $\mathrm{j}$ and $\bar{x}_{J}$ the mean income of the group. $T_{j}$ is the Theil within the group $j$ and it takes the form of:

$$
T_{j}=\frac{1}{n} \sum_{i=1}^{n} \frac{x_{i \mid j}}{\bar{x}_{J}} \ln \left(\frac{x_{i \mid j}}{\bar{x}_{J}}\right)
$$

where $\mathrm{n}$ is the number of people in the $\mathrm{j}^{\text {th }}$ group and $x_{i \mid j}$ is the individual wage of individual $i$ in group $j$. One drawback of the Theil index and of all other inequality measures based on the logarithm is that zeroes lead to the index being undefined. Households with no income are, therefore, excluded. This is unproblematic in our case because there are virtually no households with zero total household income.

\section{Results}

\subsection{Individual earnings}

We first focus on individual earnings to distinguish the evolution of women's working hours from changes in hourly wages. Table 2 presents descriptive statistics to assess individual-level hypotheses $\mathrm{H} 1$ and $\mathrm{H} 2 .{ }^{8}$ First, we look at the evolution of working types. The share of non-working women has declined from $38 \%$ in 2000

$7 \quad$ This has to be taken into account when results from factor decompositions are interpreted. To test hypotheses $3 \mathrm{a}$ and $3 \mathrm{~b}$, which focus on couples, we will additionally report correlations for couple households. Moreover, our results show relatively stable percentages of single households over time. It is therefore unlikely that changes in the household composition explain changes over time.

8 We opted for simple descriptive accounts rather than for a more formal decomposition into hourly wage, working hours and correlations for two reasons. The first is that the decomposition requires a logarithmic transformation, which we find inappropriate for working hours. The second is that the decomposition relies on the coefficient of variation, which is highly sensitive to outliers. 
Table 2 Descriptive statistics on women's working hours, hourly wages and yearly earnings, 2000, 2004, 2009 and 2014

\begin{tabular}{l|cc|cc|cc|cc}
\hline Women & 2000 & SD & 2004 & SD & 2009 & SD & 2014 & SD \\
\hline Working type (in \%) & & & & & & & & \\
0-5 hours & 38.4 & & 28.6 & & 21.4 & & 19.9 & \\
6-19 hours & 14.2 & & 15.5 & & 15.6 & & 12.9 & \\
20-35 hours & 21.6 & & 26.5 & & 32.7 & & 32.0 & \\
36+ hours & 25.8 & & 29.4 & & 30.3 & & 35.2 & \\
total & 100 & & 100 & & 100 & & 100 & \\
N & 2928 & & 3192 & & 2580 & & 3973 & \\
Working hours (weekly) & & & & & & & & \\
working women: mean & 29.4 & $(12.6)$ & 29.8 & $(12.2)$ & 29.9 & $(11.9)$ & 31.3 & $(11.4)$ \\
all women (inc. inactive): & 18.3 & $(17.3)$ & 21.5 & $(16.8)$ & 23.6 & $(16.1)$ & 25.2 & $(16.1)$ \\
mean & & & & & & & & \\
N & 2928 & & 3192 & & 2580 & & 3973 & \\
Hourly wage & & & & & & & & \\
6-19 hours: mean & 39.1 & $(30.2)$ & 32.6 & $(21.4)$ & 34.5 & $(22.1)$ & 35.5 & $(24.9)$ \\
20-35 hours: mean & 36.0 & $(17.4)$ & 33.0 & $(12.9)$ & 35.5 & $(15.6)$ & 35.4 & $(14.3)$ \\
36+ hours: mean & 33.1 & $(12.3)$ & 33.1 & $(12.4)$ & 34.6 & $(14.9)$ & 34.2 & $(13.6)$ \\
theil index & 0.121 & $(0.009)$ & 0.104 & $(0.008)$ & 0.104 & $(0.009)$ & 0.107 & $(0.009)$ \\
correlation hours-wage & -0.12 & & -0.05 & & -0.02 & & -0.09 & \\
N & 1599 & & 1913 & & 1760 & & 2664 & \\
Yearly earnings & & & & & & & & \\
all (incl. inactive): Theil & 0.252 & $(0.016)$ & 0.280 & $(0.009)$ & 0.258 & $(0.011)$ & 0.236 & $(0.009)$ \\
index & & & & & & & & \\
working: Theil index & 0.190 & $(0.015)$ & 0.194 & $(0.007)$ & 0.180 & $(0.009)$ & 0.187 & $(0.008)$ \\
N & 3416 & & 4062 & & 3119 & & 4929 & \\
\hline
\end{tabular}

Notes: Women between 25 and 64 years of age. Standard deviation (sd) in parenthesis. Working hours have been top-coded at 45 hours. Hourly wages have been deflated using 2005 as the base year. Yearly earnings include imputed values provided in the CNEF-File of the SHP.

Source: SHP 2000-2014, own calculations.

to $20 \%$ in 2014 . In addition, active women have increased their work percentage and full-time work has risen from 26\% of all women in 2000 to 35\% in 2014. Similarly, the share of higher part-time work (21-35 hours per week) has increased from $22 \%$ to $32 \%$, while fewer women have a low percentage (from 14.2 to 12.9 ). Another indication that part-time working women have intensified their labour supply is the shrinking variation in hours worked (standard deviation declined from 12.6 in 2000 to 11.4 in 2014). We thus find that both entry into the labour market and shifts within active women (as expected in $\mathrm{H} 1 \mathrm{a}$ and $\mathrm{H} 1 \mathrm{~b}$ ) are responsible for 
the decreasing variation of working hours and have contributed to lower earnings inequality at the individual level.

The next step is the link between working hours and the wage level. Table 2 shows similar hourly wage levels for smaller part-time, higher part-time and fulltime work. Although we cannot formally test whether there is a part-time penalty with these descriptive statistics, results illustrate that part-time work is not restricted to low-qualified jobs in Switzerland. ${ }^{9}$ Accordingly, there is no correlation between hourly wage and working hours, which means that the channel proposed in $\mathrm{H} 2$ does not seem relevant for Switzerland. ${ }^{10}$ Summing up our findings on women's earnings inequality $(\mathrm{H} 1, \mathrm{H} 2)$, we see that rising female labour force participation has clearly reduced women's earnings inequality.

\subsection{Household income}

\subsubsection{Income sources}

We now switch to the household level to test our remaining hypotheses ( $\mathrm{H} 3-\mathrm{H} 5)$. Before addressing the hypotheses, we first discuss the inequality decomposition by income source (men's earnings, women's earnings and other income components) as presented in Table 3.

Total household inequality seems to have slightly decreased since 2000 (both significant for Theil and CV), which is in line with official statistics on income inequality (SFSO 2014). Looking separately at the trends of the three income sources, we notice that inequality in men's earnings has remained constant over time, whereas women's earnings and other household income have become more equally distributed. ${ }^{11}$ From the analysis at the individual level, we know that the decline in women's earnings can be uniquely attributed to the variation in working hours rather than to the distribution of the wage level, as the latter has remained stable. ${ }^{12}$ The analysis at the individual level has also shown that both entry into the labour market and increasing work percentages have contributed to this equalising effect. In addition, the higher earnings inequality among women compared to men (1.12 vs 0.78 in 2014) can be explained by their higher variation in working hours

9 Further confirmation is provided by decomposition of the Theil index by work type, where the distinction between small part-time, high part-time and full-time explains less than $0.3 \%$ of wage inequality.

10 Although the years shown in Table 2 suggest a negative correlation, the coefficient is positive in other years. Distinguishing wage quintiles, we find that women in the middle part of the wage distribution ( $3^{\text {rd }}$ and $4^{\text {th }}$ quintiles) work slightly more than women with lower or higher wages.

11 A more detailed analysis of other income shows that income inequality has decreased for private transfers, public transfers and, to a lesser extent, imputed rent. Inequality in asset income and social security pensions show no clear trend.

12 Although a more detailed analysis on wage inequality is beyond the scope of this article, we want to point to the role of the data sources. While population surveys such as the SHP and the Swiss Labour Force Survey suggest a rather stable wage inequality, the Swiss Earnings Structure Survey shows increasing inequality in hourly wages because it covers very high wages (Suter et al. 2016). 
Table 3 Decomposition of household income inequality by income source

\begin{tabular}{|c|c|c|c|c|c|c|c|c|c|c|c|c|}
\hline & \multicolumn{5}{|c|}{ Coefficient of variation } & \multicolumn{3}{|c|}{$\begin{array}{c}\text { Income share } \\
\text { (in } \% \text {, total }=100 \% \text { ) }\end{array}$} & \multicolumn{4}{|c|}{ Correlation } \\
\hline & total & men & women & other & $\begin{array}{c}\text { working } \\
\text { women }\end{array}$ & men & women & other & $\begin{array}{r}\text { women/ } \\
\text { men }\end{array}$ & $\begin{array}{r}\text { women/ } \\
\text { other }\end{array}$ & $\begin{array}{l}\text { men/ } \\
\text { other }\end{array}$ & $\begin{array}{l}\text { women/ } \\
\text { men couple }\end{array}$ \\
\hline \multirow[t]{2}{*}{2000} & 0.572 & 0.734 & 1.313 & 2.581 & 0.983 & 66.3 & 24.9 & 8.8 & -0.16 & 0.00 & -0.09 & 0.00 \\
\hline & $(0.011)$ & $(0.012)$ & $(0.025)$ & $(0.012)$ & $(0.021)$ & & & & & & & \\
\hline \multirow[t]{2}{*}{2004} & 0.582 & 0.789 & 1.279 & 2.162 & 0.980 & 62.8 & 26.4 & 10.9 & -0.17 & -0.02 & -0.09 & 0.02 \\
\hline & $(0.013)$ & $(0.016)$ & $(0.032)$ & $(0.016)$ & $(0.028)$ & & & & & & & \\
\hline \multirow[t]{2}{*}{2009} & 0.507 & 0.740 & 1.141 & 1.818 & 0.909 & 59.9 & 29.7 & 10.4 & -0.19 & -0.02 & -0.18 & 0.00 \\
\hline & $(0.011)$ & $(0.015)$ & $(0.027)$ & $(0.071)$ & $(0.024)$ & & & & & & & \\
\hline \multirow[t]{2}{*}{2014} & 0.528 & 0.775 & 1.123 & 1.655 & 0.864 & 59.6 & 28.6 & 11.8 & -0.18 & -0.04 & -0.09 & 0.03 \\
\hline & $(0.011)$ & $(0.016)$ & $(0.021)$ & $(0.046)$ & $(0.018)$ & & & & & & & \\
\hline
\end{tabular}

Notes: Standard errors of the coefficients of variation are included in parenthesis. For correlation of couples, couples where both partners are between 25 and 64 have been selected. $n$ of households: 3589 (2000), 4307 (2004), 3261 (2009) and 5186 (2014).

Source: SHP 2000-2014.

rather than by a higher variation in wage levels. Comparing all income sources, we notice that inequality in each separate income source is higher than inequality in household income, reflecting the strong equalising effect of aggregation and income pooling at the household level. ${ }^{13}$

Turning to the correlation between income factors in Table 3, we see that men's earnings are negatively related to women's earnings ( -0.16 in 2000 and -0.18 in 2014). Furthermore, the correlation shows no time trend. The negativity can be explained by the fact that the sample includes not only couples, but also single households and other household members (e. g. children and parents, brothers and sisters, flatmates). To be able to test $\mathrm{H} 3 \mathrm{a}$ and $\mathrm{H} 3 \mathrm{~b}$ (referring to the correlation between partners), Table 3 also provides the correlation for couples in which both partners are between 25 and 64 years old. These coefficients are very close to zero and do not show any time trend. Overall, we can say that neither H3a (which predicted a more positive correlation over time) nor $\mathrm{H} 3 \mathrm{~b}$ (which predicted a less positive correlation over time) is supported. This is truly a different finding from those reported in other studies (Cancian and Reed 1999; Schwartz 2010; Harkness 2013), ${ }^{14}$ which show positive and strengthening correlations between spouses' earn-

13 As a robustness check, we have performed as far as possible the same analysis with data from the Swiss Labour Force Survey, which has the advantages of dating back to 1991, providing larger sample sizes and fresh samples every year. Because of serious shortcomings in the data (e. g. only one person per household was interviewed and large measurement errors in household income), we just mention that the equalising effect of increasing female labour force participation was also observed during the 1990s, and that the evolution since 2000 is comparable to results in the SHP. For example, replicating the sample selection in Harkness's study, we find more strongly negative coefficients than in any other country. For all households (including non-couple households) 
Figure 2 Weekly working hours of women by wage quintile of their partner for 2000 and 2014

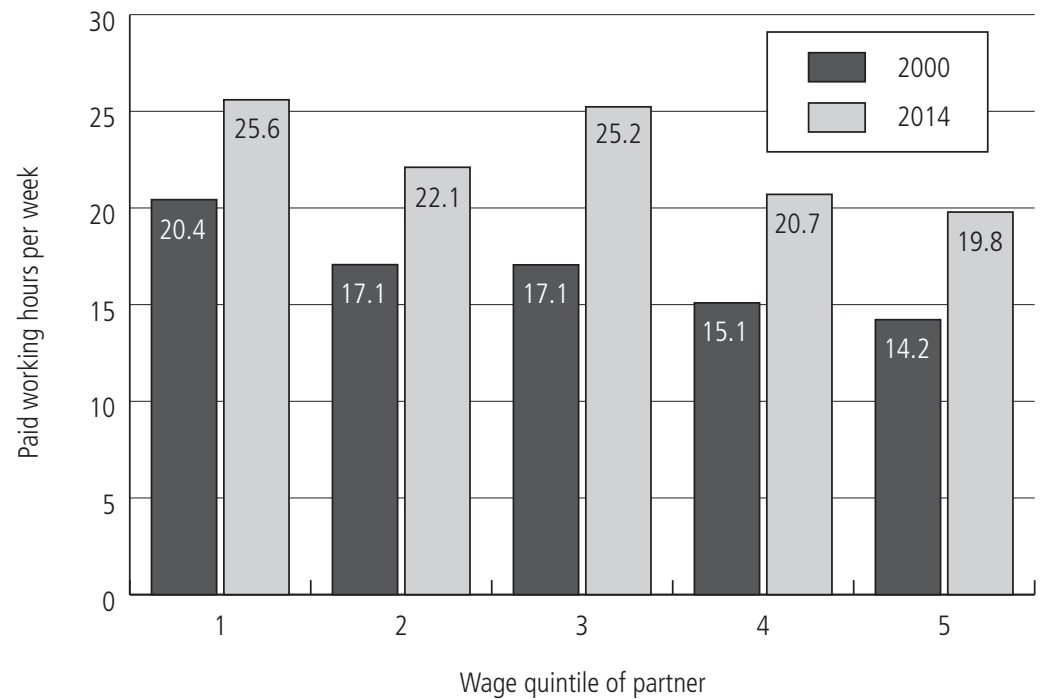

Notes: All women 25-64 years of age living with their partner (including inactive); working hours top-coded at 45 hours/week; n: 1410 in 2000, 2178 in 2014.

Source: SHP 2000 and 2014.

ings over time. To understand which women increased their working hours, Figure 2 shows women's working hours by the earnings quintile of their partner. We see that women's working hours clearly decline with the wage level of their partner. In 2014, women with partners in the highest quintile worked six hours less per week than women with partners in the lowest quintile. ${ }^{15}$ This difference has remained constant since 2000 because women in all quintiles have increased their working hours in a similar way. Interestingly, such a clear pattern is no longer observed in other countries (OECD 2015). The explanation of the negative relation between women's working hours and partner's wages deserves further analysis for future studies.

Coming back to the decomposition of household income inequality by income component, we now address H4. Table 3 reveals that men's earnings are still

the correlation coefficient in Switzerland amounts to -0.15 (for 2005), which is clearly below estimates for any other country (the lowest in Harkness's study is Luxemburg, with -0.03). Selecting couples only, the correlation in Switzerland is 0.04 (in 2005), while the other countries show correlations from 0.11 in Germany to 0.36 in Finland.

15 Women with partners in the highest quintile are older (46 years on average,) than women with partners in the lowest earnings quintile (39 years on average). In contrast, having young children is not related to the partner's wage level. The negative relation between working hours and partner's wages holds both for participation and the working hours of active women. 
Table 4 Counterfactual distribution of household income for changes between 2000 and 2014 (coefficient of variation)

\begin{tabular}{|c|c|c|c|c|c|c|}
\hline & \multicolumn{2}{|c|}{$2000-2014$} & \multicolumn{2}{|c|}{$2000-2009$} & \multicolumn{2}{|c|}{ 2004-2014 } \\
\hline & CV & $\begin{array}{l}\text { change } \\
\text { since t0 }\end{array}$ & CV & $\begin{array}{l}\text { change } \\
\text { since t0 }\end{array}$ & CV & $\begin{array}{l}\text { change } \\
\text { since t0 }\end{array}$ \\
\hline Coefficient of variation (CV) t0 & 0.572 & & 0.572 & & 0.582 & \\
\hline (1) women's inequality to t1 & 0.552 & $-3.4 \%$ & 0.554 & $-11.2 \%$ & 0.564 & $-2.9 \%$ \\
\hline (2) men's inequality to t1 & 0.592 & $3.5 \%$ & 0.574 & $-3.1 \%$ & 0.575 & $-1.1 \%$ \\
\hline (3) inequality in other income to 11 & 0.551 & $-3.6 \%$ & 0.554 & $0.5 \%$ & 0.567 & $-2.5 \%$ \\
\hline (4) correlation of female income to t1 & 0.559 & $-2.3 \%$ & 0.559 & $-3.1 \%$ & 0.569 & $-2.1 \%$ \\
\hline (5) all income shares to t1 & 0.593 & $3.7 \%$ & 0.587 & $-2.3 \%$ & 0.584 & $0.4 \%$ \\
\hline (6) share of female earnings to $t 1$ & 0.575 & $0.6 \%$ & 0.577 & $2.6 \%$ & 0.582 & $0.1 \%$ \\
\hline (7) all women's values to t1 & 0.535 & $-6.3 \%$ & 0.537 & $-6.0 \%$ & 0.550 & $-5.5 \%$ \\
\hline Coefficient of variation t1 & 0.529 & $-7.5 \%$ & 0.507 & $-11.2 \%$ & 0.529 & $-9.1 \%$ \\
\hline $\begin{array}{l}\text { Change } \mathrm{t} 1-\mathrm{t} 0 \text { explained by women's } \\
\text { labour force participation }\end{array}$ & & $84.0 \%$ & & $53.7 \%$ & & $60.1 \%$ \\
\hline
\end{tabular}

Source: SHP 2000-2014.

the most important income component, accounting for $66.3 \%$ of total household income in 2000 and $59.6 \%$ in 2014. In parallel, although this share has stagnated since 2009, the contribution of women's earnings to household income has grown from $24.9 \%$ in 2000 to $28.6 \%$ in 2014 . Whether this change is equalising remains an open question because women's earnings inequality is lower than inequality in other income sources, but higher than inequality in men's earnings. In order to properly test $\mathrm{H} 4$ (effect of higher contribution of female earnings on household income), we conduct a shift-share analysis (Table 4), which also tests the overall effect of increased female labour force participation on household income inequality. Because the selection of the years influences the results, we show the effect for three different time intervals. The first row shows the $\mathrm{CV}$ in $\mathrm{t} 0$, the second row shows the $\mathrm{CV}$ assuming that only inequality in women's earnings $\left(\mathrm{CV}_{\mathrm{f}}\right)$ increases to 11 level, keeping factor shares, inequality in other factors and correlations among factors constant as in $\mathrm{t} 0$. In this scenario, inequality declines by $3.4 \%$ from 2000 to 2014. If we adjust the correlation between female earnings and other income sources (men's earnings and other income) to their 2014 values (counterfactual 4), we find that the $\mathrm{CV}$ is $2.3 \%$ lower than in 2000 . In counterfactual 5 , we change all the income shares to their 2014 values. This change increases inequality by $3.7 \%$, which is due to the higher importance of (highly unequal) income of other sources for household income. If we change only the share of female earnings while keeping 
the other factors constant (counterfactual 6) ${ }^{16}$ the $\mathrm{CV}$ changes by less than $1 \%$, which is against our expectations for $\mathrm{H} 5$.

Most importantly, Table 4 shows the inequality level assuming that only elements associated with women's labour force participation changed (correlation, women's share, inequality in women's earnings), while men's earnings and other household income remained constant. For the period 2000-2014, we find that household income inequality declines from 0.57 to $0.53(-7.5 \%)$. This amounts to $84 \%$ of the real decrease in income inequality between 2000 and 2014 that can be attributed to female labour force participation. If other years are chosen, however, female labour force participation explains only $54 \%$ of the change between 2000 and 2009 and $60 \%$ of the change between 2004 and 2014. This shows that rising female earnings have contributed to the small decline in household income inequality in Switzerland.

\subsubsection{Household types}

The decomposition by factor shares comes with some limitations, as it can neither show the effect of part-time work nor address the effects of changing household structure. Therefore, we conduct decompositions by household types as described in the methodological part. We distinguish ten groups: male-breadwinner couples (1), female-breadwinner couples (2), couples where the man works full-time and the woman part-time (3), couples where the woman works full-time and the man part-time (4), full-time working couples (5), and couples where both either work part-time or do not work (6), single women (7), single men (8), single mothers (9) and other households (10), which consist mostly of couples living with children who contribute to household income. ${ }^{17}$

Results are presented in Table 5. If not stated otherwise, the discussed changes are significant at the $95 \%$ confidence level. The ten household types explain $15.7 \%$ of total inequality in 2000 and almost the same share (15.1\%) in 2014. Most of the inequality is thus within groups. We first address the role of single and single-mother households to test $\mathrm{H} 5$. The share of single women has remained relatively stable, which means that $\mathrm{H} 5$ a can be rejected. ${ }^{18}$ Interestingly, more households composed by single women would not even have increased household income inequality because the income level of and inequality in this group are close to the population averages. The situation is slightly different for single men, who show a high average income (ca 23\% above the population average) and high (within) inequality level in

16 We divided income shares from men's earnings and other earnings in 2000 by 0.95 (100-women's share in 2014)/(100-women's share in 2000), so that the income shares of the counterfactual distribution add up to $100 \%$.

17 Couples whose children are younger than 18 years old or earn less than CHF 24000 per year are considered couple households.

18 Although Table 5 suggests an increasing share of single men, a closer examination reveals that this evolution is due to weights provided by the SHP. We choose nevertheless to use weighted data because unweighted data bring other biases. 
Table 5

Decomposition of household income inequality by household types in 2000 and 2014

\begin{tabular}{lrrrrrr}
\hline & Share & Share & Income & Income & Theil & Theil \\
& 2000 & 2014 & 2000 & 2014 & 2000 & 2014 \\
\hline Couple: male breadwinner & $31.8 \%$ & $19.1 \%$ & 0.831 & 0.791 & 0.144 & 0.134 \\
Couple: female breadwinner & $2.6 \%$ & $3.5 \%$ & 0.692 & 0.846 & 0.268 & 0.129 \\
Couple: man full-, woman part-time & $26.8 \%$ & $30.1 \%$ & 1.113 & 1.051 & 0.118 & 0.084 \\
Couple: woman full-, man part-time & $1.1 \%$ & $1.9 \%$ & 1.036 & 1.192 & 0.055 & 0.086 \\
Couple: both full-time & $6.9 \%$ & $9.2 \%$ & 1.553 & 1.421 & 0.080 & 0.069 \\
Couple: both part-time or inactive & $6.2 \%$ & $7.8 \%$ & 0.668 & 0.768 & 0.227 & 0.157 \\
Single women & $4.2 \%$ & $4.3 \%$ & 0.994 & 0.928 & 0.136 & 0.114 \\
Single man & $3.6 \%$ & $4.7 \%$ & 1.230 & 1.224 & 0.105 & 0.162 \\
Single mother & $4.4 \%$ & $3.6 \%$ & 0.673 & 0.709 & 0.128 & 0.145 \\
Other households (other earners & $12.5 \%$ & $15.8 \%$ & 1.170 & 1.055 & 0.091 & 0.088 \\
than couple) & & & & & & \\
Overall & $100.0 \%$ & $100.0 \%$ & 1.000 & 1.000 & 0.149 & 0.122 \\
\% between household types & & & & & $15.7 \%$ & $15.1 \%$ \\
\hline
\end{tabular}

Notes: Income refers to the ratio of mean income of each household type to the population mean income. n of households: 3589 (2000) and 5186 (2014).

Source: SHP 2000 and 2014.

2014. In contrast, single-mother households have the lowest average income of all household types and a high level of within-group inequality. Given that the share of single mothers has decreased over time, this socio-demographic aspect have not affected inequality (H5b).

After testing the effect of the household composition, we look more closely at couple households. Most importantly, the share of male-breadwinner couples has declined from $31.8 \%$ of all working-age households in 2000 to only $19.1 \%$ in 2014, whereas the share of full-time working men and part-time working women increased from $26.8 \%$ to $30.1 \%$. Full-time working couples have also become more common $(6.9 \%$ in $2000,9.2 \%$ in 2014$)$, whereas couples with a main female earner remained marginal. It is interesting to compare the inequality and income levels within these household types. Single-breadwinner households are more unequal than dual-earner households (the difference is significant in 2014, but it just misses the significance level in 2000) and have a low average household income ( $83 \%$ and $79 \%$ of average income). The abandonment of the male-breadwinner model thus contributes to a more equal distribution of household income. Turning to the comparison of part-time and full-time working women, we see that the inequality within groups is lower when both partners work full-time, probably reflecting the heterogeneity of working hours among part-time working women. Because full- 


\begin{tabular}{lcccr}
\hline & \multicolumn{4}{c}{ Counterfactual analysis } \\
& 2000 & In \% & 2014 & In \% \\
\hline Theil index & 0.149 & & 0.122 & \\
$1-0$ hh. switch to 1-0.5 h. & 0.133 & $-10.7 \%$ & 0.107 & $-11.7 \%$ \\
$1-0.5$ hh. switch to 1-1 hh. & 0.154 & $3.6 \%$ & 0.128 & $5.0 \%$ \\
\hline
\end{tabular}

Notes: 1-0 hh. indicates male-breadwinner households; $1-0.5 \mathrm{hh}$. indicates households where men work full-time and women work part-time and 1-1 hh. indicates household where both partners work full-time. Source: SHP 2000 and 2014.

time working couples have high incomes (1.55 times the average income in 2000 and 1.42 times the average income in 2014), the effect of a switch from part-time to full-time work on income inequality remains ambiguous and requires additional analysis, which we present below. Turning to low work-intense couple households, we notice that their inequality appears to be quite high. This is probably because the reasons for low participation in the labour market vary considerably (e. g. from income-rich households whose members do not need to work to unskilled household members excluded from the labour market). ${ }^{19}$

In order to properly estimate the equalising potential of more working women and to compare part-time and full-time work, we have computed a counterfactual analysis with the Theil index in 2000 and 2014 (Table 6). A limitation of this approach is that selection effects are not taken into account. For example, the counterfactual assumes that inactive women would have similar earnings as women already working. In the first counterfactual, we simulate that all inactive partnered women enter the labour market as part-time workers, which means that all 1-0 type households (group 1) switch to the 1-0.5 type (group 3) keeping other proportions, within-group inequality and mean earnings constant. The Theil index in this scenario declines by $10.7 \%$ in 2000 and by $11.7 \%$ in 2014 . In the second counterfactual, we simulate that all part-time working women living with a partner switch to full-time, which means that all 1-0.5 type households (group 3) switch to the 1-1 type (group 5) assuming that other elements remain constant. This shows that more full-time work relative to part-time work has little impact on household income inequality (3.6\% in $2000,5.0 \%$ in 2014$)$. Nevertheless, the effect points to more income inequality. ${ }^{20}$

19 We have also carried out a decomposition of the inequality change proposed by Mookherjee and Shorrocks (1982) for the MLD (mean log deviation). The MLD of household income declined from 0.156 in 2000 to 0.125 in 2014 . We can attribute $75 \%$ of this decline to inequality within groups, $21 \%$ to changes in relative incomes and only $4 \%$ to changes in the proportions.

20 Taking account of the fact that part-time working women tend to have higher earning partners than full-time working women (Figure 2), the adverse effect of more full-time work on inequality is likely to be underestimated in the counterfactuals in Table 6 . 


\section{Conclusion}

This study is a contribution to the growing literature addressing the consequences of demographic changes on household income inequality. While many studies have focused on the rising share of single households, we find that the most striking changes in household types in Switzerland have occurred within couples, as dualearning couples have replaced the dominant male-breadwinner family. Our analysis has shown that this evolution has kept household income inequality relatively low in Switzerland. Moreover, the small decline in inequality levels observed since 2000 can mainly be attributed to increasing female labour force participation.

Among the different channels linking female earnings and household income inequality, the homogenisation of women's working hours is the most important. Both women who enter the labour market and part-time working women who augment their work percentage have contributed to the lower variation of working hours, which translates into lower household income inequality. In contrast, potentially offsetting factors, such as a part-time wage penalty or an increasing correlation of partners' earnings, are not relevant for this country. Women over the entire income distribution have increased their participation and working hours to a similar extent.

The very weak correlation of partners' earnings in Switzerland is striking in comparison to studies on other countries that report positive and strengthening correlations between partners' earnings. One of the reasons for this Swiss particularity is that women with high-earning partners work less than women with low-earning partners. The tax system, progressive child-care costs, attitudes, the gender pay gap and weak assortative mating could be potential explanations, that need to be addressed in future studies.

While there is extensive evidence that women's entry into the labour market reduces household income inequality, the differences between part-time and full-time work with respect to household inequality have been neglected by previous studies. Even though our analysis shows clear equalising effects of female labour force participation in general, we find that switching from part-time to full-time work has little impact on income inequality, and that this impact even points towards more household income inequality. Comparative studies are needed to test whether this result is particular to Switzerland. About half of working-age women work part-time (between 6 and 35 hours per week), and most of them work more than 50\%. The average hourly wages of full-time working women and of women with small and high part-time percentages are very close. This means that, in Switzerland, parttime work contributes to income inequality only through the variation in working hours and not through the variation in hourly wages.

While our analysis shows clear equalising effects of female labour force participation up to 2014, the scope for future effects is limited. Considering the high activity rate, the potential of labour-market entry is limited. Furthermore, an increase in 
full-time work relative to part-time work is not a means to lower household income inequality further in Switzerland. However, women who increase their working hours from small work percentages could be beneficial for household income inequality.

Our findings are more than a confirmation of previous studies. The Swiss case shows that increased female labour force participation is equalising even in a context of high female labour force participation. Another important result is that from the perspective of household income inequality, part-time work is not detrimental, but rather beneficial. We can conclude by saying that high female labour force participation has not come at the price of higher income inequality.

\section{$7 \quad$ References}

Blossfeld, Hans-Peter, and Sandra Buchholz. 2009. Increasing Resource Inequality among Families in Modern Societies: The Mechanisms of Growing Educational Homogamy, Changes in the Division of Work in the Family and the Decline of the Male Breadwinner Model. Journal of Comparative Family Studies 40(4): 603-616.

Breen, Richard, and Leire Salazar. 2010. Has Increased Women's Educational Attainment Led to Greater Earnings Inequality in the United Kingdom? A Multivariate Decomposition Analysis. European Sociological Review 26(2): 143-157.

Bühler, Elisabeth, Carmen Brun, Martin Steinmann, and Marie-Claude Brulhardt. 2002. Atlas suisse des femmes et de l'égalité. Zurich: Seismo.

Bütler, Monika, and Martin Ruesch. 2009. Wenn die Arbeit mehr Kostet als sie einbringt. Studie über die Auswirkungen der Besteuerung und Krippenkosten auf die Erwerbstätigkeit der Frauen. Westschweizer Gleichstellungskonferenz egalite.ch.

Cancian, Maria, and Deborah Reed. 1999. The Impact of Wives' Earnings on Income Inequality: Issues and Estimates. Demography 36(2): 173-184.

Cancian, Maria, and Robert F. Schoeni. 1998. Wives' Earnings and the Level and Distribution of Married Couples' Earnings in Developed Countries. Journal of Income Distribution 8(1): 45-61.

Daly, Mary C., and Robert G. Valletta. 2006. Inequality and Poverty in United States: The Effects of Rising Dispersion of Men's Earnings and Changing Family Behaviour. Economica 73(289): 75-98.

Del Boca, Daniela, and Silvia Pasqua. 2003. Employment Patterns of Husbands and Wives and Family Income Distribution in Italy (1977-1998). Review of Income and Wealth 49(2): 221-245.

Ernst, Carol, Michael Gerfin, and Robert E Leu. 2000. Inequality Trends in the Swiss Income Distribution. Swiss Journal of Economics and Statistics 136(3): 289-306.

Esping-Andersen, Gøsta. 2007. Sociological Explanations of Changing Income Distributions. American Behavioral Scientist 50(5): 639-658.

Esping-Andersen, Gøsta. 2009. Incomplete Revolution: Adapting Welfare States to Women's New Roles. Cambridge, UK: Polity Press.

Eurostat. 2015. Gini Coefficient of Equivalised Disposable Income in 2013 (source:SILC), http:// ec.europa.eu/eurostat/web/income-and-living-conditions/data/main-tables (24.02.2015).

Gerfin, Michael, and Robert E. Leu. 2007. Evaluating the Cost-Effectiveness of in-Work Benefits: A Simulation Study for Switzerland. German Economic Review 8: 447-467.

Harkness, Susan. 2013. Women's Employment and Household Income Inequality. Pp. 207-233 in Income Inequality: Economic Disparities and the Middle Class in Affluent Countries, edited by Gornick, Janet. Stanford, CA: Stanford University Press. 
Jenkins, Stephen P. 1995. Accounting for Inequality Trends: Decomposition Analyses for the UK, 1971-86. Economica 62(245): 29-63.

Karoly, Lynn A., and Gary Burtless. 1995. Demographic Change, Rising Earnings Inequality, and the Distribution of Personal Well-Being, 1959-1989. Demography 32(3): 379-405.

Kollmeyer, Christopher. 2012. Family Structure, Female Employment, and National Income Inequality: A Cross-National Study of 16 Western Countries. European Sociological Review 29(4): 816-827.

Larrimore, Jeff. 2014. Accounting for United States Household Income Inequality Trends: The Changing Importance of Household Structure and Male and Female Labor Earnings Inequality. Review of Income and Wealth 60(4): 613-1001.

Mookherjee, Dilip, and Anthony Shorrocks. 1982. A Decomposition Analysis of the Trend in UK Income Inequality. The Economic Journal 92(368): 886-902.

OECD. 2013. OECD Economic Surveys: Switzerland 2013. Paris: OECD Publishing.

OECD. 2015. In It Together: Why Less Inequality Benefits All. Paris: OECD Publishing.

OECD StatExtract. 2015. Full-time Part-time Employment Based on National Definitions, http://Stats. Oecd.Org/ (24.02.2015).

Pasqua, Silvia. 2008. Wives' Work and Income Distribution in European Countries. The European Journal of Comparative Economics 5(2): 157-186.

Pencavel, John. 2006. A Life Cycle Perspective on Changes in Earnings Inequality among Married Men and Women. Review of Economics and Statistics 88(2): 232-242.

Piketty, Thomas. 2014. Capital in the Twenty-First Century. Cambridge, MA: Harvard University Press.

Ryscavage, Paul, Gordon Green, and Edward Welniak. 1992. The Impact of Demographic, Social, and Economic Change on the Distribution of Income. Pp. 11-30 in Studies in the Distribution of Income. Current Population Reports, Series P60, No. 183. Washington, DC: U.S. Census Bureau.

Salverda, Wiemer, Brian Nolan, and Timothy M. Smeeding. 2009. The Oxford Handbook of Economic Inequality. Oxford, UK: Oxford University Press.

Schwartz, Christine R. 2010. Earnings Inequality and the Changing Association between Spouses' Earnings1. American Journal of Sociology 115(5): 1524-1557.

Schwegler, Regina, Susanne Stern, and Rolf Iten. 2012. Familienfreundliche Steuer- und Tarifsysteme Vergleich der Kantone Basel-Stadt und Zürich. Zurich: Infras.

SFSO (Swiss Federal Statistical Office). 2014. Répartition de la richesse en Suisse. Rapport du Conseil fedéral en réponse au postulat du 7 décembre 2010 déposé par Jacqueline Fehr (10.4046). Neuchâtel: SFSO.

Shorrocks, A. F. 1982. Inequality Decomposition by Factor Components. Econometrica 50(1): 193-211.

Suter, Christian, Ursina Kuhn, Pascale Gazareth, Eric Crettaz, and Laura Ravazzini. 2016. Considering the Various Data Sources, Survey Types and Indicators: To What Extent Do Conclusions Regarding Changing Income Inequality in Switzerland since the Early 1990s Converge? Pp. 153-183 in Essays on Inequality and Integration, edited by Axel Franzen, Ben Jann, Christian Joppke, and Eric Widmer. Zurich: Seismo.

Western, Bruce, Deirdre Bloome, and Christine Percheski. 2008. Inequality among American Families with Children, 1975 to 2005. American Sociological Review 73(6): 903-920. 


\section{Seismo Questions de genre}

\section{Sous la direction de Jean-Marie Le Goff et René Levy Devenir parents, devenir inégaux Transition à la parentalité et inégalités de genre}

Devenir parent, donc la transition à la parentalité, marque les parcours de vie par une multitude de changements touchant autant les partenaires que leur couple: transformation de la division du travail, reconfiguration du réseau social, ajustements identitaires... Souvent, ces changements rapprochent l'organisation du couple des rôles traditionnels de père et de mère, modèle qui inclut également les inégalités de genre. Le présent ouvrage vise à comprendre les mécanismes sociaux à l'œuvre dans la manifestation des inégalités entre les hommes et les femmes au moment de la naissance de leur premier enfant dans le contexte social et institutionnel de la Suisse.

Le livre présente les résultats d'un projet interdisciplinaire regroupant des psychologues, psychologues sociaux, sociologues et démographes. L'étude a été réalisée en Suisse romande, associant matériaux quantitatifs et qualitatifs sur la transition à la parenta-

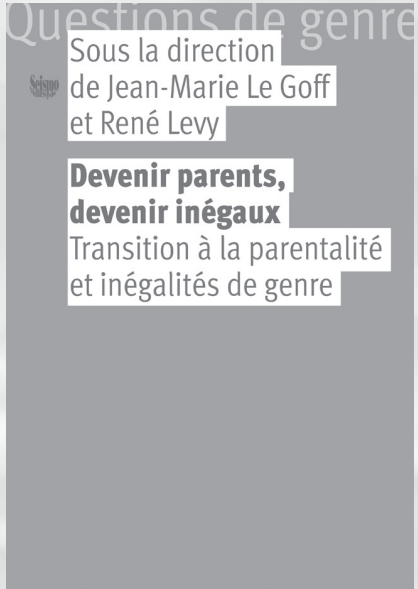

ISBN 978-2-88351-071-5, 352 pages, Fr. 48. - / Euro 43.lité et relevés en trois vagues autour de la naissance d'un premier enfant.

Jean-Marie Le Goff est démographe, maitre d'enseignement et de recherche à l'Université de Lausanne et chercheur associé au NCCR Lives. Il a participé à l'élaboration du projet devenir parent et de l'enquête Devenir parent, puis a été chef de projet de la collecte des données de cette enquête.

René Levy est sociologue (inégalités sociales, rapports sociaux de sexe, parcours de vie), professeur émérite à l'Université de Lausanne, ancien directeur du centre Pavie. Il a dirigé le projet Devenir parent. 